\title{
Study of cold formed steel beam column joint to resist lateral load
}

\author{
Erma Desmaliana ${ }^{1, *}$, Bernardinus Herbudiman ${ }^{1}$, Andi Mentari Ulfayani ${ }^{1}$, and Fauzi Ahmad \\ Shobur Gunawan ${ }^{1}$ \\ ${ }^{1}$ Department of Civil Engineering, Institut Teknologi Nasional Bandung, Bandung, Indonesia
}

\begin{abstract}
Cold Formed Steel (CFS) is one of the materials that recently used in building structures. There are many advantages of CFS compared with other materials, such as lightweight, high tensile strength, and fast construction. Hollow Structural Sections (HSS) is the most commonly used as beam and column CFS sections. The purposes of this study are determining the behavior and capacity of CFS beam column joint under lateral load with manual calculation, numerical analysis and experimental. The test specimens used $1 \mathrm{~mm}$ thick, $4 \times 4 \mathrm{~cm}$ HSS for column and $2 \times 4 \mathrm{~cm}$ HSS for beam. Beam and column connected by two single angle plates placed above and below the beam sides. Both parallel and staggered fastener configurations used in this experiment. Four $4 \mathrm{~mm}$ diameter bolts used in this connection. Monotonic static loading applied on beam for modelling the lateral load. The experimental results show the behavior and the capacity of the beam column joint with parallel fastener configurations. The numerical results show that the staggered fastener configuration has better performance compared with the parallel fastener configuration. The CFS beam column joint are adequate to resist the lateral load and feasible to be apply as structural components in building structures.
\end{abstract}

\section{Introduction}

Nowadays the use of cold-formed steel (CFS) is famous as building construction materials than other materials because of lighter, higher strength, more economical, and more durable. Cold-formed steel is very thin with a thickness ranging from $0.75 \mathrm{~mm}$ to $4 \mathrm{~mm}$. The yield strength of cold-formed steel is $230-340 \mathrm{MPa}$. The CFS is coated with zinc or mixture of zinc and aluminium to protect it from corrosion. It is usually used as a secondary member such as side rails, roof purlins, and wall cladding. These members are connected by bolts, screws, rivets or by special fasteners. The role of fasteners has a significant influence on building construction, especially for determining bolted fasteners or additional stiffener Connections are the physical components which mechanically fasten the structural element and important to transfer force and moment from main structural members to the supporting element.

Beam-to-column connections are one of the most important structural members on the building construction. In building construction, the building failures are caused by the

\footnotetext{
*Corresponding author: ermadesmaliana@itenas.ac.id
} 
occurrence of failures on beam-to-column connections. The behavior of beam to column connections influence all of the structural systems and occurs between rigid connections and semi-rigid connections. The structural behavior cold-formed steel sections construction as beam to column connections is different from hot rolled steel sections construction due to the thickness of the connected parts of the cold-formed steel sections.

Twelve beam to column connections between cold-formed steel sections consisting of three beam depths and four connection types were tested in isolation to investigate their behavior based on strength, stiffness, and ductility. Generally, most of the connections possess the strength and ductility to be considered as partial strength connections. The ultimate failures of almost all of the connections were due to local buckling of the compression web and flange elements of the beam closest to the connection [1].

The ultimate load value of bolted joint is $16 \mathrm{kN}$ for I-section and $11 \mathrm{kN}$ for C-section from the non-linear finite element analysis of cold-formed steel beam-column connections. From the analysis, it is evident that I-section is behaving dominantly in withstanding axial load oven Channel-section. Further, this implies the advantage of having bolted joints in lightweight steel structures [2].

The ultimate load value of bolted joint is $18 \mathrm{kN}$ at flange-connection and $23 \mathrm{kN}$ at webconnection for I-section, also $8 \mathrm{kN}$ at flange-connection and $15 \mathrm{kN}$ at web-connection for $\mathrm{C}$-section from the non-linear finite element analysis of cold-formed steel beam-column connections. I-sections are economical for lightweight cold-formed steel structures. Web connection provides better results than flange portion connections of the beam. The flexural member being connected by the joints at the web position of the compression member has a greater impact in the structural behavior under loaded condition. The futuristic technology application regarding cold-formed steel in steel structures can increase the usage of cold roll steel as a primary structural member in lightweight structures [3].

The failure of connection with a single row of screws and a double row of screws using beam column connector at the junction in FEM analysis are due to the torsional buckling of the beam at the point of the load applied. The failure of connection by angle plate along with beam column connector at the junction using single rows of screws and double of screws in FEM analysis are due to the distortion of angle plate as well as distortion of the beam-column connector. The connection with single row of screws and double row of screws using beam column connector at the junction have more rotation and less amount load of $1.2 \mathrm{kN}$ and $0.9 \mathrm{kN}$ so they are not recommended than the connection by angle plate along with beam column connector at the junction using single rows of screws and double of screws that have load of $2 \mathrm{kN}$ and $3.4 \mathrm{kN} \mathrm{[4].}$

In this research, beam, and column connected by two single-angle-plates placed above and below the beam sides with parallel and staggered fastener configurations. The purposes of this research are determining the behavior and capacity of cold-formed steel beam to column connections under lateral load. $4 \times 4 \mathrm{~cm}$ square HSS for column, $2 \times 4 \mathrm{~cm}$ rectangular HSS for beam, and $2 \times 2.5 \mathrm{~cm}$ angles. The beam is bolted directly to the column without bracing.

\section{Methodology}

This research uses the experimental method with a monotonic test on the specimens that are loaded laterally to measure the deflection with LVDT (Lateral Vertical Displacement Transducer) and to observe the failure pattern visually such as yielding and buckling as shown in Fig. 1. Specimens use two type of fastener configurations on two dimensional of beam to column connections that are pushed by the incremental lateral load at the end of the beam. The static monotonic loading is done to obtain the maximum stress. On testing, 
the loading stage of the specimens is carried out at the rate of $1 \mathrm{~mm} / \mathrm{sec}$ based on control stroke.

The test specimens are used 1-mm-thick, $4 \times 4 \mathrm{~cm}$ HSS for the column, $2 \times 4 \mathrm{~cm}$ HSS for the beam, and two $2 \times 2.5 \mathrm{~cm}$ single-angle-plates to connect beam-column. Four $4 \mathrm{~mm}$ diameter bolts with grade 4.6 that refer to ISO 989-1 are used in this connections.

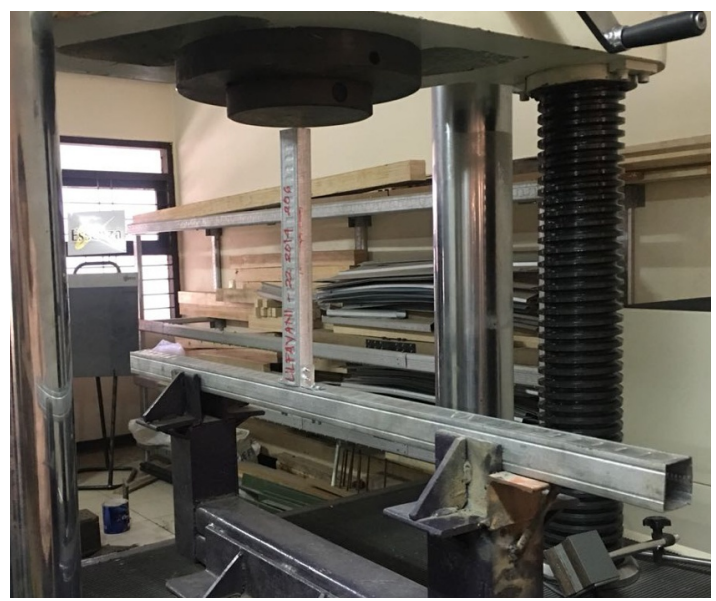

Fig. 1. Testing set-up of CFS beam to column connections.

The lateral load of CFS beam-to-column connections with various fastener configurations can be predicted by manual calculation based on Indonesian Standard (SNI) that refer to Australian Standard as shown in Eq. 1, Eq. 2, and Eq. 3. This predicted lateral load would be compared with the result of beam-to-column connections testing.

$$
\begin{gathered}
M_{\mathrm{n}}\left(\lambda \leq \lambda_{\mathrm{p}}\right)=F_{\mathrm{y}} Z \\
M_{\mathrm{n}}\left(\lambda_{\mathrm{p}}<\lambda \leq \lambda_{\mathrm{r}}\right)=\left[M_{\mathrm{p}}-\left(M_{\mathrm{p}}-M_{\mathrm{r}}\right)\left(\lambda-\lambda_{\mathrm{p}} / \lambda_{\mathrm{r}}-\lambda_{\mathrm{p}}\right)\right] \\
M_{\mathrm{n}}\left(\lambda>\lambda_{\mathrm{p}}\right)=F_{\mathrm{y}} S_{\text {eff }}
\end{gathered}
$$

The test result of the beam-to-column connection with lateral load also will be compared with the result of numerical analysis from FEM software.

\section{Results and discussion}

In this experimental study, the lateral load of CFS beam to column connections could be predicted from the manual calculation based on SNI and numerical analysis from Ansys as shown in Table 1.

Table 1. The results of calculation lateral load of beam-to-column connections.

\begin{tabular}{|c|c|c|c|}
\hline \multirow{2}{*}{ Configurations } & \multicolumn{3}{|c|}{ Load (N) } \\
\cline { 2 - 4 } & Manual & Numerical & Experimental \\
\hline Parallel & 1093 & 360 & 310 \\
\hline Staggered & 1123 & 390 & 340 \\
\hline
\end{tabular}


The predicted lateral load with numerical analysis for fasteners parallel configurations approaches the result of the experimental lateral load, so the numerical analysis is worth recommended to predict the lateral load of CFS beam to column connections. From the numerical results of a lateral load of beam-to-column connections with parallel and staggered configurations (Fig. 3. and Fig. 4.) show the failure is considered when the stress reaches the yield strength of the section, the yield strength of the section used is $550 \mathrm{MPa}$.
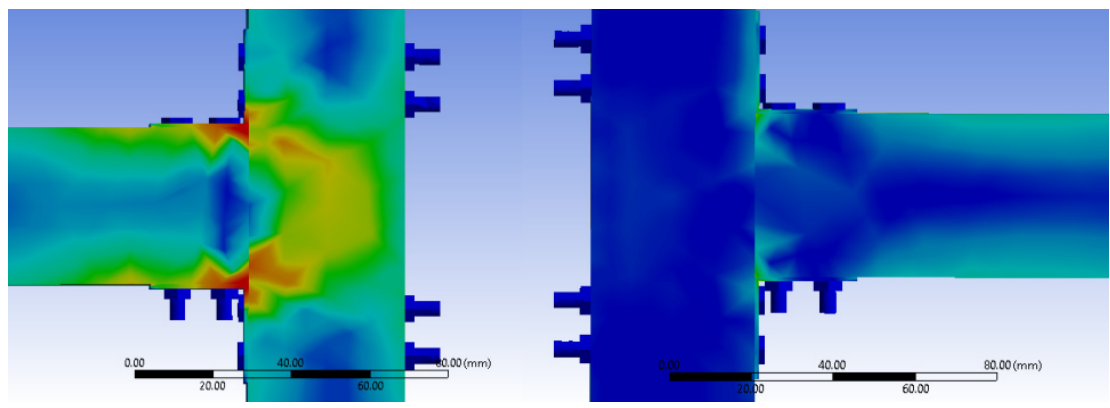

(a)

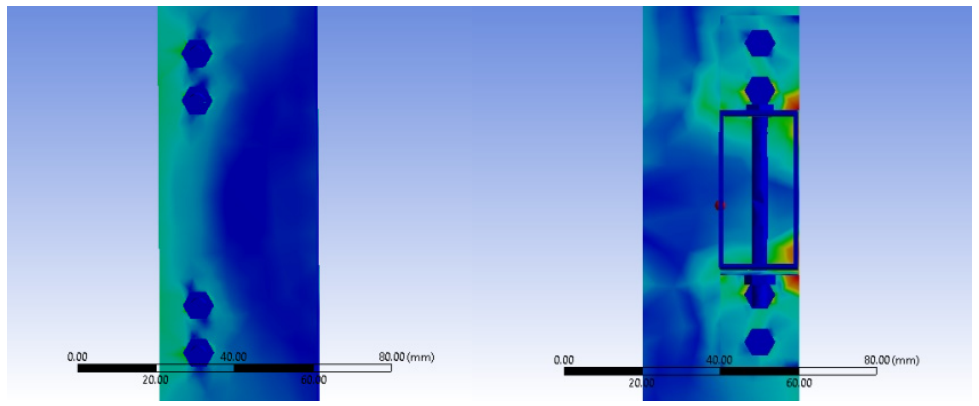

(b)

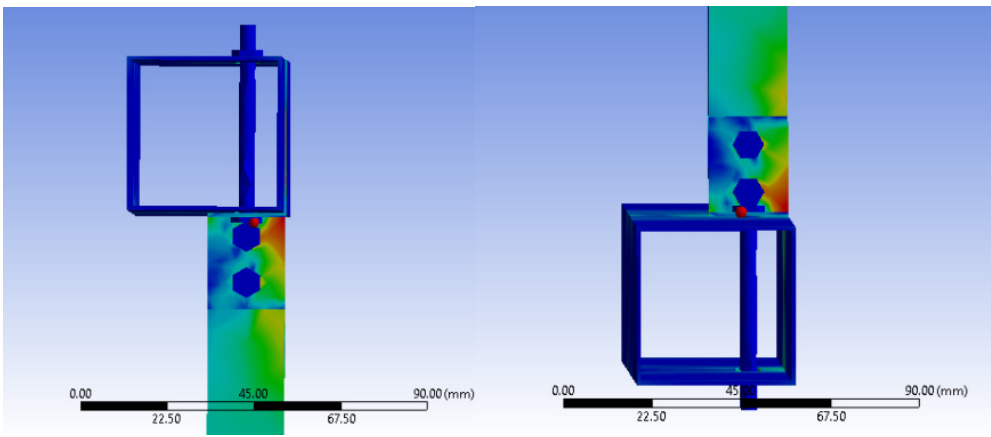

(c)

Fig. 3. Stress distribution on CFS beam-to-column connections with parallel fastener configurations from (a) side; (b) front; (c) top.

Based on Fig. 3(a), it occurs buckling failure around the column area is shown by the yellow stress distribution around the column area. From Fig. 4(a), it occurs buckling failure around the column area is shown by the yellowish orange stress distribution around the column area. 


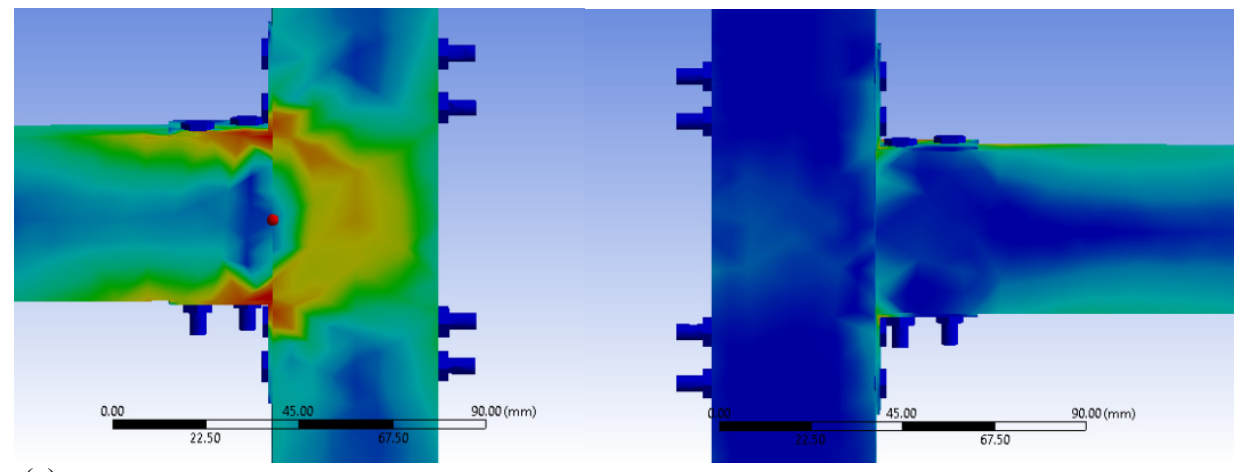

(a)

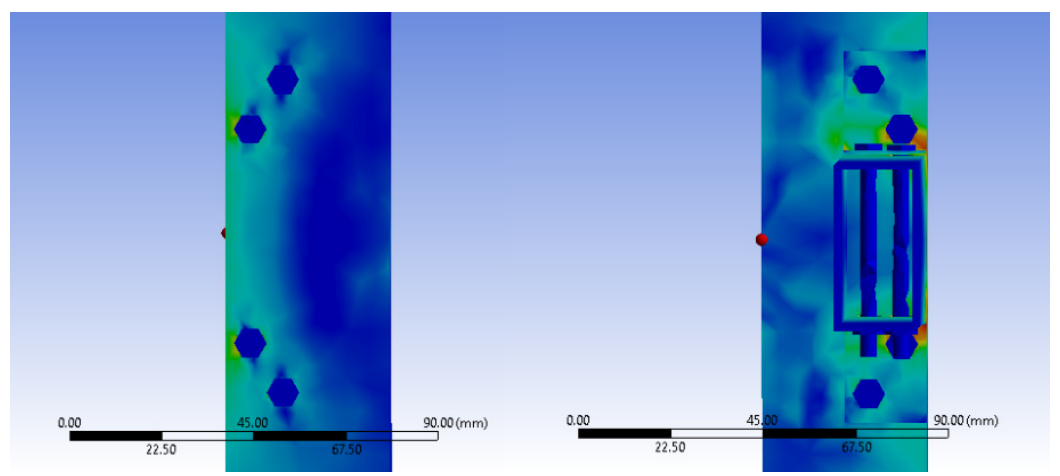

(b)

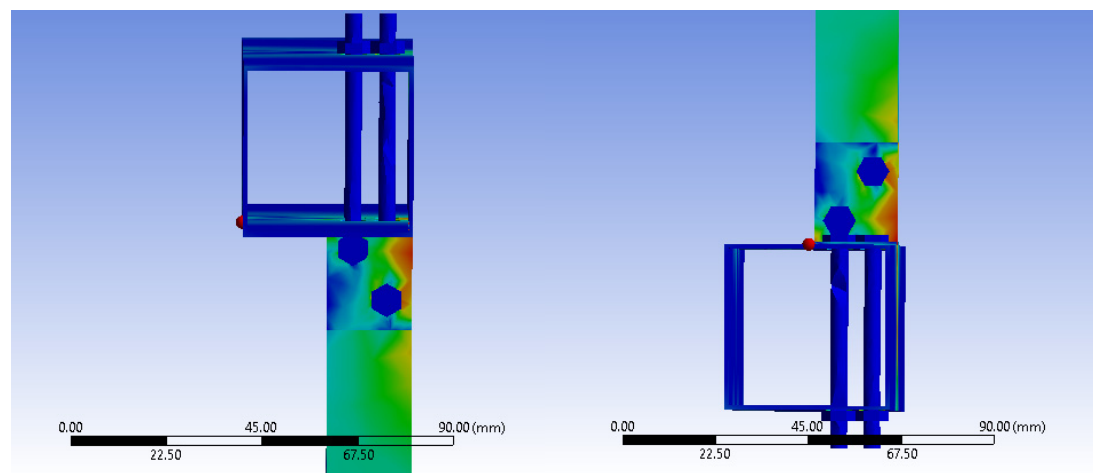

(c)

Fig. 4. Stress distribution on CFS beam-to-column connections with staggered fastener configurations from (a) side; (b) front; (c) top.

From the test results of static monotonic loading of CFS beam-to-column connections (Fig. 5), it shows the failure that occurs is elastic lateral buckling on the column at the CFS beam-to-column connections.

Specimen 1 has a greater maximum lateral load carrying capacity of CFS beam-tocolumn connections than specimen 2 . The average lateral load carrying capacity of specimens is $310 \mathrm{~N}$; therefore, the result approaches numerical analysis. Due to buckling failure around the column area, a diaphragm or stiffener can be added to increase lateral load carrying capacity of CFS beam-to-column connections (Fig. 6), therefore, the maximum stress distribution occurs around the stiffener. The lateral load carrying capacity of CFS beam-to-column connections with a stiffener plate is $720 \mathrm{~N}$; therefore, a diaphragm or stiffener is effective eliminate the buckling failure. 

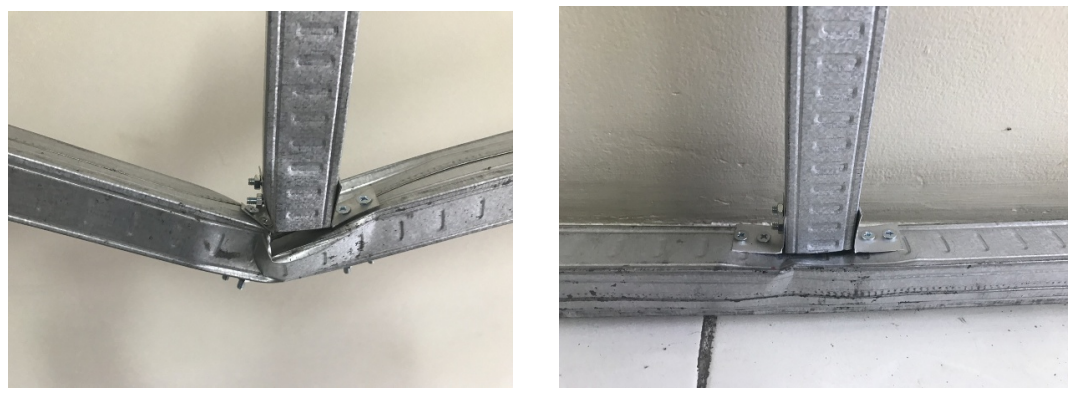

Fig. 5. Static monotonic loading test of CFS beam-to-column connections specimen 1 and 2.

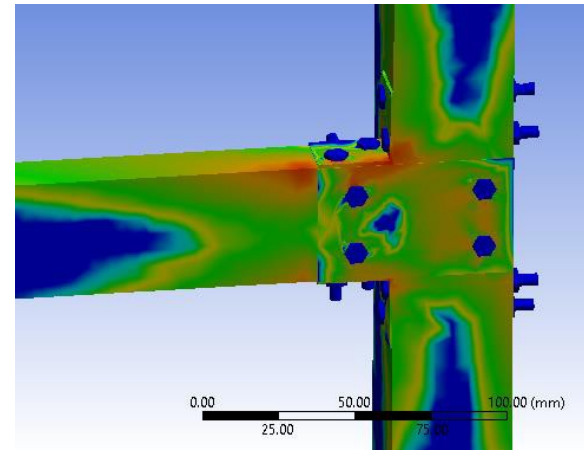

Fig. 6. Stress distribution on CFS beam-to-column connections with a stiffener plate.

\section{Conclusions}

The CFS beam-to-column connections with staggered configurations have a maximum lateral load of $390 \mathrm{~N}$, which is greater than the CFS beam-to-column connections with parallel configurations. The failure of CFS beam-to-column connections with all the various configurations is buckling on the column at the connections, either numerical analysis or experimental results. Numerical analysis is eligible to predict the lateral load carrying capacity of CFS beam-to-column connections because the calculations approach the experimental results. The presence of stress concentration on the column at the CFS beam-to-column connections, as shown from numerical analysis, cause elastic lateral buckling; therefore, the load carrying capacity can be confirmed by experimental results.

The result of manual calculations is far from the numerical and experimental because of elastic lateral torsional buckling (LTB). Therefore, it is recommended to calculate the stability aspects in more detail because it can greatly reduce the flexural capacity of columns. To minimise elastic LTB, it can also be recommended to add a diaphragm or stiffener so that the HSS column is stable.

\section{References}

1. H.A. Hamid, M. Mahendran, Proc. of the $21^{\text {st }}$ ACMSM (2010)

2. S. Rajintha, A.S. Sattainathan, N.K. Vinoth, Int. J. of Innovative Research in Science, Engineering and Technology 7, 5 (2018)

3. A.S. Sattainathan, S. Rajintha, Jayashree, Int. Res. J. of Eng. and Tech. 5, 6 (2018)

4. P.M. Pol, M. Mogali, Int. Res. J. of Eng. and Tech. 4, 8 (2017) 